\title{
A systematic review to determine the impact of non steroidal antiinflammatory drugs on dental implant osseointegration
}

DOI:

10.1111/ors. 12443

\section{Document Version}

Accepted author manuscript

Link to publication record in Manchester Research Explorer

Citation for published version (APA):

Dave, M., \& Patel, N. (2020). A systematic review to determine the impact of nonsteroidal antiinflammatory drugs on dental implant osseointegration. Oral Surgery, 13(1). https://doi.org/10.1111/ors.12443

\section{Published in:}

Oral Surgery

\section{Citing this paper}

Please note that where the full-text provided on Manchester Research Explorer is the Author Accepted Manuscript or Proof version this may differ from the final Published version. If citing, it is advised that you check and use the publisher's definitive version.

\section{General rights}

Copyright and moral rights for the publications made accessible in the Research Explorer are retained by the authors and/or other copyright owners and it is a condition of accessing publications that users recognise and abide by the legal requirements associated with these rights.

\section{Takedown policy}

If you believe that this document breaches copyright please refer to the University of Manchester's Takedown Procedures [http://man.ac.uk/04Y6Bo] or contact uml.scholarlycommunications@manchester.ac.uk providing relevant details, so we can investigate your claim.

\section{OPEN ACCESS}




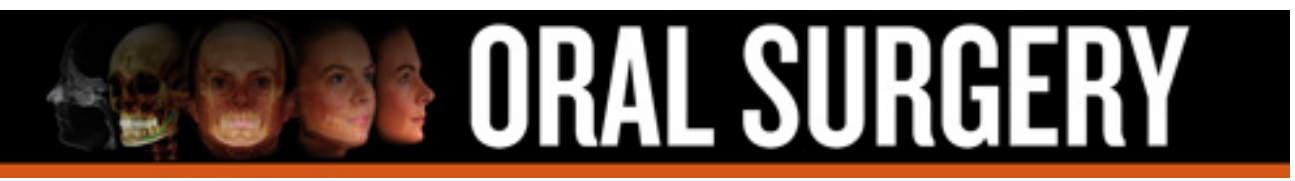

\section{A systematic review to determine the impact of non- steroidal anti-inflammatory drugs on dental implant osseointegration}

\begin{tabular}{|c|c|}
\hline Journal: & Oral Surgery \\
\hline Manuscript ID & ORS-02-19-RE-1387.R2 \\
\hline Manuscript Type: & Review \\
\hline $\begin{array}{l}\text { Date Submitted by the } \\
\text { Author: }\end{array}$ & $\mathrm{n} / \mathrm{a}$ \\
\hline Complete List of Authors: & $\begin{array}{l}\text { Dave, Manas; The University of Manchester, Division of Dentistry; } \\
\text { Newcastle Dental Hospital } \\
\text { Patel, Neil; University Dental Hospital of Manchester, Oral Surgery }\end{array}$ \\
\hline Keywords: & $\begin{array}{l}\text { Dental Implants, Non-Steroidal Anti-Inflammatory Agents, } \\
\text { Osseointegration < Dental Implants, Oral Surgery }\end{array}$ \\
\hline
\end{tabular}


Title: A systematic review to determine the impact of non-steroidal anti-inflammatory drugs on dental implant osseointegration

Running title: Effect of NSAIDs on dental implants

Authors:

Manas Dave a,b BSc (Hons), BDS (Hons), MJDF RCS (Eng), MFDS RCPS (Glasg), PGCert, PGCert.

General Professional Trainee, Newcastle Dental Hospital, United Kingdom.

University of Manchester, United Kingdom ${ }^{\mathrm{I}}$

manas.dave@postgrad.manchester.ac.uk

Neil Patel b BDS (Hons), MFDS RCS (Ed), MJDF RCS (Eng), MSc, MOralSurg RCS (Eng), PG Cert, MDTFEd, SFHEA.

Lecturer in Oral Surgery, University of Manchester, United Kingdom I

neil.patel@manchester.ac.uk

I - permanent address and main affiliation address

A - Newcastle Dental Hospital

Richardson Road

Newcastle Upon Tyne

NE2 4AZ

United Kingdom

B - Division of Dentistry, School of Medical Sciences, 
Faculty of Biology, Medicine and Health

The University of Manchester

Manchester Academic Health Science Centre

Oxford Road

Manchester

M13 9PL

United Kingdom

Corresponding Author

Manas Dave

Permanent address

Manas Dave

Division of Dentistry, School of Medical Sciences,

Faculty of Biology, Medicine and Health

The University of Manchester

Manchester Academic Health Science Centre

Oxford Road

Manchester

M13 9PL

United Kingdom

Telephone: +44 (0) 1613066000

Acknowledgements

Nil

Page $\mathbf{2}$ of $\mathbf{3 0}$ 


\section{$\underline{\text { Abstract }}$}

Introduction: Non-steroidal anti-inflammatory drugs (NSAIDs) are commonly used over the counter analgesics for the management of post-operative pain following dental surgery, including dental implant placement. NSAIDs work through inhibition of the cyclo-oxygenase (COX) enzyme, in particular the isoform COX-2.

COX-2 has been shown to induce new bone formation with upregulation of COX-2 demonstrated following bony fractures. The aim of this systematic review was to determine if NSAID use affects bone healing and osseointegration following dental implant placement.

Methods: Electronic databases (Medline and Embase) were searched in addition to hand searches from reference lists of selected papers. Only randomised control trials were included in this review.

Results: Three studies were included and data provided on bone healing and osseointegration following dental implant surgery (with and without NSAID use) were analysed. The Cochrane risk of bias tool (2.0) were used to assess risk of bias.

Two randomised control trials were conducted on animal subjects and one on human participants. One animal study reported significantly reduced bone healing around dental implants following the use of prolonged subcutaneous NSAIDs. No other studies reported any significant findings. There was considerable heterogeneity between included studies.

Conclusion: There is limited evidence exploring the relationship of NSAIDs and dental implant osseointegration and bone healing to draw definitive conclusions. Further research is required in this area. 


\section{Key Words:}

Dental Implants

Anti-Inflammatory Agents, Non-Steroidal

Surgery, Oral

Osseointegration

17
18
19
20
21
22
23
2
2
26
27
28
29
30
3
32
33
34
35
36
37
38
39
40
4
42
43
4
45
46
47
48
49
50
51
52
53
5
55
56
57
58
60




\section{$\underline{\text { Introduction }}$}

There are a number of options available to patients for the fixed replacement of missing teeth. Over the last twenty years, dental implants have been an ever increasing and popular choice to restore edentulous spaces ranging from a single tooth to full arch prosthesis.

Numerous studies have investigated dental implants in different clinical situations, reporting success rates over $94 \% .{ }^{1-3}$ Nonetheless, there are local and systemic risk factors that can lead to unsuccessful osseointegration and failure of the implant (table 1). Additionally, operator factors such as site selection, implant dimensions (length/width) and technique can affect the overall success of the procedure. ${ }^{4}$

Bone undergoes continual remodelling through life to maintain the integrity of the skeleton. This is primarily achieved through the cellular mechanisms of osteoblasts, which produce organic bone matrix, and osteoclasts that break down bone mineral. ${ }^{5}$ Dental implant placement produces physiological similarities with bone fracture injury through initiation of a regenerative process. Initially, the fracture ruptures blood vessels resulting in haematoma formation and the release of pro-inflammatory cytokines such as tumour necrosis factor, transforming growth factor $\beta$ and interlukin- 6 amongst many others. ${ }^{6}$ These generate a chemotactic gradient facilitating cellular infiltration, inducing the release of inflammatory mediators such as cyclo-oxygenase enzyme isoform $2(\mathrm{COX}-2)$ and progression through the reparative phase of the inflammatory process. ${ }^{7,8} \mathrm{An}$ initial haematoma is formed and a fibrin clot, protecting the exposed underlying tissue. Proliferation of periosteal cells is followed by its differentiation into a number of cell types, notably chondroblasts and osteoblasts that produce hyaline cartilage and osteoid (woven bone) respectively. In addition, mechanical stress stimulates the activation of osteoclasts, which resorb damaged bone. Osteoblasts migrate into the site and produce osteoid which forms a scaffold and together with the 
hyaline cartilage results in a fracture callus. This tissue is replaced through endochondral ossification into lamellar bone. ${ }^{9-11}$ The fracture healing process results in bone deposition around the implant hence implant topography that favours osseointegration and long-term maintenance of bone to implant contact are important in stability and resistance to forces. ${ }^{11}$, 12 The cellular mechanism of bone remodelling is summarised in figure 1 .

Non-steroidal anti-inflammatory drugs (NSAIDs) are commonly used analgesics which can often be obtained by patients in the United Kingdom without a prescription, summarised in table 2.

They are effective in reducing post-operative pain from dental surgical procedures (compared to acetaminophen (paracetamol) alone). ${ }^{13}$ The mechanism of action of NSAIDs works through inhibition of the COX enzyme, in particular the isoform COX-2. This in turn reduces prostaglandin production and other mediators of acute inflammation, producing their antipyretic, anti-inflammatory and analgesic properties. ${ }^{14-16} \mathrm{COX}$ inhibition is also responsible for a number of side effects including gastro-irritation, interstitial nephritis, reduced glomerular filtration rate and prolonged bleeding time amongst many others. ${ }^{17}$ NSAIDs have also been documented to increase the risk of acute myocardial infarction with the risk greatest in the first month of treatment especially with high doses. 18,19

COX-2 (and its associated mediators) have been shown to induce bone formation, however as these enzymes are inhibited by NSAIDs, it has been postulated that their use could affect bone healing and dental implant osseointegration. ${ }^{20-23}$ Furthermore, COX-2 knockout mice demonstrate significantly delayed fracture repairs in comparison to COX-1 knockout and wild type mice. ${ }^{20}$

Key factors in dental implant osseointegration include primary stability which is immediate stability following surgery whereas secondary stability follows bone remodelling around the 
implant interface. ${ }^{24}$ Bone quality varies according to site such as the posterior maxilla where reduced bone density can compromise implant stability. ${ }^{25}$ In such instances, techniques such as immediate loading need to be approached with caution. Studies have shown conditions that affect bone quality such as osteoporosis to also pose similar challenges for implant stability. 26

Success of dental implants are measured through a range of parameters well defined by Smith and Zarb (1989). ${ }^{27}$ These include no adverse patient symptoms, immobility of the implant, no radiographic evidence of peri-implant pathosis and stability in bone levels. ${ }^{27}$ There are a range of implant success criteria that are well evaluated by Papaspyridakos et al (2012). ${ }^{28}$

As NSAIDs are common forms of pain relief following dental implant placement and have been shown to affect the physiology of bone remodelling, it is of interest to investigate whether they have an impact on bone healing, osseointegration and success rates following dental implant placement. Therefore, the aim of this systematic review was to evaluate the current evidence basis for NSAIDs affecting bone healing and osseointegration following dental implant placement. 


\section{Methods}

A preliminary search was conducted to determine the highest quality of evidence to help inform the search strategy. It was determined that there were a limited number of studies exclusively assessing NSAID use and dental implants hence search criterion were kept broad to include as many studies as possible (table 3 ). In addition, no language restrictions were placed.

\section{$\underline{\text { Inclusion criteria }}$}

The following inclusion criteria were applied to search results:

- Randomised control trials only.

- Human and animal studies.

- Titanium implants only.

- Implant surgery must have been the first implant surgery in the site of placement (inclusive for local anaesthetic, intravenous sedation, general anaesthetic and primary or secondary care). Single and multiple implants placed were allowed.

- NSAID use must be clearly documented and administered either pre, peri or post operatively (no restrictions on mode of delivery or dose were placed).

- At least one of the success criteria defined by Smith and Zarb (1989) must be recorded in the study. The criteria have been adapted to include quantitative bone analysis without a specified follow up duration. No limiting timeframe was set to account for animal based studies.

- Immediate placement, delayed placement with all loading protocols were acceptable. Implants loaded following three months were defined as delayed. 


\section{$\underline{\text { Exclusion criteria }}$}

Guided bone regeneration procedures would influence the physiological process of healing and act as a potential confounder, hence studies including patients who had undergone such procedures either prior to or during the time of implant placement were excluded. ${ }^{29}$ In addition, patients with medical conditions that could affect bone healing such as those immunocompromised, with metabolic bone disease or malignancy were excluded. Studies where it was not possible to differentiate the results between smokers and non-smokers were also excluded. It was determined that a large number of NSAIDs are available 'over the counter', hence it would not be possible to exclude patients who had previously taken NSAIDs accurately however patients taking NSAIDs for ongoing medical conditions would not be included as this may influence overall COX expression.

An electronic search was conducted from databases Medline (1946 to December 2018) and Embase (1980 to December 2018). In addition, hand searching from reference lists of selected papers were also conducted. Titles of identified papers were initially screened by both authors and all identified studies included for full text review. Both authors (MD and $\mathrm{NP}$ ) independently reviewed all studies using the search protocol and inclusion and exclusion criteria to determine studies for inclusion in this systematic review. Any issues were discussed by both authors until an consensus was reached. The search strategy and results are presented in table 4. The Cochrane risk of bias tool for randomised control trials (RoB 2) was used to assess risk of bias for included studies. 


\section{$\underline{\text { Results }}$}

The initial search provided 99 studies with 33 duplicates that were identified and removed. Additional manual searches were performed which identified one further study. The remaining 67 studies had their titles and abstracts evaluated and excluded if they were not relevant, did not meet the inclusion criteria or fulfilled the exclusion criteria. If there were any ambiguity at this point, the studies were included for full review. Seven articles were selected and following full text analysis, four were excluded. ${ }^{30,31}$ The flow of studies through the review process is shown in the PRISMA flow diagram (figure 2). Three randomised control trials were included for review (summarised in table 5).

\section{$\underline{\text { Risk of bias assessment }}$}

All included studies were assessed using the Cochrane risk of bias tool (2.0) independently by both authors and results compared to ensure accuracy (table 6). Only one included study had a low overall risk of bias. Two studies did not provide sufficient detail on the randomisation process, specifically there was missing information on the random sequence generation process and concealment (for the investigators only as both are animal based studies). Consequently, both studies were determined to have an overall uncertain risk of bias. ${ }^{32,33}$

\section{$\underline{\text { Key Findings }}$}

Three randomised control trials were included in this review, of which two were animal studies. ${ }^{32-35}$ Ribeiro et al. (2006) conducted a randomised control trial (with animal subjects) and reported a significant difference in bone healing around dental implants for the group 
administered subcutaneous Meloxicam (versus saline) for 60 days. ${ }^{33}$ The other two randomised control trials included in this review used oral and subcutaneous NSAID delivery modes and did not find any significant differences with the use of NSAIDs and post-surgery bone healing or dental implant osseointegration.

Animal studies utilised the tibiae (rats) and calvaria (rabbits) for the site of implant placement. The human study used dentoalveolar bone and included both the maxillae and mandible. Methods of implant surgery were documented in detail in all studies. Outcomes measures included quantitative analysis using micro-CT, histological analysis (following sacrifice of animal subjects) and radiographic analysis. There was a lack of homogeneity in the results hence it was not possible to conduct a meta-analysis or other forms of quantitative analysis. A summary of the key findings are presented in table 5.

\section{$\underline{\text { Discussion }}$}

Parallels can be drawn between dental implant surgery in the craniofacial skeleton and bone fracture repair. Firstly, there is (iatrogenic) blood vessel damage causing haemorrhaging of blood products. This causes platelets and inflammatory cells to release of a number of factors such as platelet derived growth factor, vaso-endothelial growth factor, transforming growth factor $\beta$ and bone morphogenic protein (BMP). ${ }^{36}$ Inflammatory mediators released at the fracture site produce a chemotactic gradient resulting in migration of mesenchymal cells (stromal stem cells) into the site. In addition, tissue injury causes release of phospholipase A2 which catalyses the formation of arachidonic acid (from membrane phospholipids) into a number of constituents such as prostacyclin, prostaglandins, thromboxane and leukotrienes modulated by the cyclo-oxygenase enzyme. ${ }^{37}$ 
There are two forms of the cyclo-oxygenase enzyme (COX1 and COX2). COX-1 is constituently active in most cells for physiological processes however is converted to COX-2 in states of inflammation, stress and other pathological conditions. ${ }^{8,38} \mathrm{COX}-2$ has been shown to potentiate the inflammatory process, mainly through the production of prostaglandins. Prostalgandin E2 (PGE2) is key compound that induces differentiation of mesenchymal cells into osteoblasts resulting in bone formation, initially as woven bone before a hard callus is formed. 39,40

NSAID interference in bone healing has been postulated to be due to COX and BMPs inhibiting local release of prostaglandins (mainly PGE2) through the blockage of the COX enzyme. There is some suggestion that mechanical loading on bone can stimulate bone formation, which can be inhibited by NSAIDs. Conversely, prostaglandins have also been shown to stimulate cyclic AMP causing bone resorption through osteoclast stimulation. ${ }^{38,41}$

The three randomised control trials included in this review provided their subjects (both animals and humans) with NSAIDs post operatively. Cai et al. (2015) conducted a randomised control trial on rabbits with a control (no pain relief), oral NSAID (Diclofenac Sodium) and subcutaneous selective COX-2 inhibitor (Parecoxib) groups. ${ }^{32}$ Drug administration was only continued for one week post dental implant surgery with the rabbits from each group sacrificed at set time intervals (weeks four and twelve). All dental implants were titanium and none were loaded. No significant histological changes were observed in the implant bone interface. Alissa et al. (2009) conducted a double-blinded randomised control trial with (human) patients receiving NSAIDs (ibuprofen) and placebos post implant placement for a one week duration. ${ }^{35}$ The implants were submerged and undistributed for a three to six month duration following which they were loaded with a prosthesis. This study radiographically measured marginal bone levels at three and six months (with respect to baseline at two weeks) and did not find any significant differences. In addition, implant 
stability was manually checked for all cases. However, the authors did not differentiate patients who had their implants loaded when reporting on marginal bone levels.

A similar non-randomised study were conducted by Sakka and Hanuneh (2013) whereby patients were allocated to a NSAID (Ibuprofen) or non-NSAID group. Similarly, NSAID use were continued for one week. ${ }^{34}$ Their study was similar to Alissa et al. (2009) where marginal bone levels were compared and no significant differences found at three monthly and six monthly intervals.

In vitro studies have shown an increased expression of COX-2 mRNA up to two weeks following a bony fracture. Hence, longer exposure to NSAIDs for its COX-2 inhibitory effect may be required to reduce osteoblast activity and record a measurable difference in osseointegration. ${ }^{20}$

Ribeiro et al. (2006) conducted a randomised control trial on rats that were divided into a control group (subcutaneous saline) and intervention group (subcutaneous NSAID Meloxicam). ${ }^{33}$ The use of saline or NSAIDs were continued for 60 days at which point the subjects were sacrificed. All dental implants were titanium and none were loaded. Histological analysis showed the NSAID group to have significantly reduced bone healing around the implants as defined through bone to implant contact and bone density. This study suggests that the long-term use of NSAIDs post-operatively could result in adverse bone healing however, caution must be exercised when interpreting these results. This is because, firstly, it is unlikely that any patient would continue pain relief for such a duration post-dental implant surgery, coupled with the mode of subcutaneous delivery. In addition, there are inherent challenges in translating the findings of animal-based studies into human applications. 
The mode of delivery of NSAIDs will impact on its bioavailability, tissue concentration and efficacy in blocking the expression of the COX enzymes. The studies included in this review utilised oral and subcutaneous forms of NSAID delivery with the latter an uncommon route for human patients for post dental implant surgery pain relief. Differences in NSAID delivery methods created challenges in making direct comparisons of the studies included in this review.

There are limitations of this systematic review, notably the inclusion of animal studies and their subsequent generalisability with human physiology. In addition, it was not possible to conduct quantitative analysis because of the heterogeneity of the results with respect to differences in NSAID delivery methods, bone measurements, species and implant surgery techniques. Therefore, the conclusions of the included studies were not suitable for further analysis.

\section{$\underline{\text { Conclusion }}$}

There is limited evidence exploring the relationship of NSAIDs and dental implant osseointegration and bone healing with the studies included in this review using different NSAIDs, delivery methods and different species. This systematic review determines that there is insufficient evidence to draw conclusions on the impact NSAIDs have on dental implant osseointegration and bone healing. There was a significant difference found with long term (60 days) NSAID use and bone healing following dental implant placement however more research is required to translate this to human findings with respective changes in dose and delivery. It would be interesting to observe dental implant success rates on patients who are on long-term NSAIDs for various medical conditions, such as patients taking prophylactic Aspirin for the prevention of cardiovascular disease. ${ }^{42}$ Long-term 
NSAID use may have a greater effect in reducing overall COX-2 expression, which could affect bone healing and osseointegration. This systematic review does not recommend any changes to current practice and clinicians may continue to recommend and prescribe NSAIDs to patients for post-operative pain relief following dental implant surgery.

\section{Conflict of interests}

The authors have no conflicts of interest or funding to declare for this article. 


\section{$\underline{\text { References }}$}

1. Karoussis IK, Salvi GE, Heitz-Mayfield LJA, Brägger U, Hämmerle CHF, Lang NP. Long-term implant prognosis in patients with and without a history of chronic periodontitis: a 10-year prospective cohort study of the ITI ${ }^{\circledR}$ Dental Implant System. Clin Oral Implants Res. $2003 ; 14(3): 329-339$.

2. Moraschini V, Poubel LAdC, Ferreira VF, Barboza EdSP. Evaluation of survival and success rates of dental implants reported in longitudinal studies with a follow-up period of at least 10 years: a systematic review. Int J Oral Maxillofac Surg. 2015;44(3):377-388.

3. Henningsen A, Smeets R, Koppen K, Sehner S, Kornmann F, Grobe A, et al. Immediate loading of subcrestally placed dental implants in anterior and premolar sites. $\mathrm{J}$ Craniomaxillofac Surg. 2017;45(11):1898-905.

4. Mohajerani H, Roozbayani R, Taherian S, Tabrizi R. The Risk Factors in Early Failure of Dental Implants: a Retrospective Study. J Dent (Shiraz). 2017;18(4):298-303.

5. Crockett JC, Rogers MJ, Coxon FP, Hocking LJ, Helfrich MH. Bone remodelling at a glance. J Cell Sci. 2011;124(7):991-998.

6. Claes L, Recknagel S, Ignatius A. Fracture healing under healthy and inflammatory conditions. Nat Rev Rheumatol. 2012; 8(3):133-143.

7. Khan AA, Iadarola M, Yang H-YT, Dionne RA. Expression of COX-1 and COX-2 in a Clinical Model of Acute Inflammation. J Pain. 2007;8(4):349-354.

8. Simon AM, Manigrasso MB, O'Connor JP. Cyclo-Oxygenase 2 Function Is Essential for Bone Fracture Healing. J Bone Miner Res. 2002;17(6):963-976.

9. Loi F, Córdova LA, Pajarinen J, Lin T-h, Yao Z, Goodman SB. Inflammation, fracture and bone repair. Bone. 2016;86:119-130.

10. Brighton CT, Hunt RM. Early histologic and ultrastructural changes in microvessels of periosteal callus. J Orthop Trauma. 1997;11(4):244-253. 
11. Schenk RK, Buser D. Osseointegration: a reality. Periodontol 2000. 1998;17:22-35.

12. Smeets R, Stadlinger B, Schwarz F, Beck-Broichsitter B, Jung O, Precht C, et al. Impact of Dental Implant Surface Modifications on Osseointegration. BioMed Res Int. 2016;2016:16.

13. Bailey E, Worthington HV, Van Wijk A, Yates JM, Coulthard P, Afzal Z. Ibuprofen and/or paracetamol (acetaminophen) for pain relief after surgical removal of lower wisdom teeth. Cochrane Database Syst Rev. 2013;12: Cd004624.

14. Cashman JN. The mechanisms of action of NSAIDs in analgesia. Drugs. 1996;52 Suppl 5:13-23.

15. Ricciotti E, FitzGerald GA. Prostaglandins and Inflammation. Arterioscler Thromb Vasc Biol. 2011;31(5):986-1000.

16. Day RO, Graham GG. Non-steroidal anti-inflammatory drugs (NSAIDs). BMJ. $2013 ; 346$.

17. Suleyman H, Demircan B, Karagoz Y. Anti-inflammatory and side effects of cyclooxygenase inhibitors. Pharmacol Rep. 2007;59(3):247-258.

18. Bally M, Dendukuri N, Rich B, Nadeau L, Helin-Salmivaara A, Garbe E, et al. Risk of acute myocardial infarction with NSAIDs in real world use: bayesian meta-analysis of individual patient data. BMJ. 2017;357:j1909.

19. Bally M, Beauchamp ME, Abrahaowicz M, Nadeau L, Brophy JM. Risk of acute myocardial infarction with real-world NSAIDs depends on dose and timing of exposure. Pharmacoepidemiol Drug Saf. 2018;27(1):69-77.

20. Zhang X, Schwarz EM, Young DA, Puzas JE, Rosier RN, O'Keefe RJ.

Cyclooxygenase-2 regulates mesenchymal cell differentiation into the osteoblast lineage and is critically involved in bone repair. J Clin Invest. 2002;109(11):1405-1415. 
21. Marquez-Lara A, Hutchinson ID, Nunez F, Jr., Smith TL, Miller AN. Nonsteroidal Anti-Inflammatory Drugs and Bone-Healing: A Systematic Review of Research Quality. JBJS Rev. 2016;4(3).

22. Gomes FI, Aragao MG, de Paulo Teixeira Pinto V, Gondim DV, Barroso FC, Silva AA, et al. Effects of nonsteroidal anti-inflammatory drugs on osseointegration: a review. The J oral implantol. 2015;41(2):219-230.

23. Thomas MV, Puleo DA. Infection, Inflammation, and Bone Regeneration: a Paradoxical Relationship. J Dent Res. 2011;90(9):1052-1061.

24. Montes CC, Pereira FA, Thome G, Alves ED, Acedo RV, de Souza JR, Melo AC, Trevilatto PC. Failing factors associated with osseointegrated dental implant loss. Implant Dent. 2007;16(4):404-412.

25. Dolanmaz D, Senel FC, Pektas Z. Dental Implants in Posterior Maxilla: Diagnostic and Treatment Aspects. Int J Dent. 2012;2012:1-2.

26. Giro G, Chambrone L, Goldstein A, Rodrigues JA, Zenóbio E, Feres M, Figueiredo LC, Cassoni A, Shibli JA. Impact of osteoporosis in dental implants: A systematic review. World J Orthop. 2015;6(2):311-315.

27. Smith DE, Zarb GA. Criteria for success of osseointegrated endosseous implants. J Prosthet Dent. 1989;62(5):567-572.

28. Papaspyridakos P, Chen CJ, Singh M, Weber HP, Gallucci GO. Success criteria in implant dentistry: a systematic review. J Dent Res. 2012;91(3):242-248.

29. Elgali I, Omar O, Dahlin C, Thomsen P. Guided bone regeneration: materials and biological mechanisms revisited. Eur J Oral Sci. 2017;125(5):315-337.

30. Winnett B, Tenenbaum HC, Ganss B, Jokstad A. Perioperative use of non-steroidal anti-inflammatory drugs might impair dental implant osseointegration. Clin Oral Implants Res. 2016;27(2):e1-7. 
31. Ribeiro FV, Nociti FH, Jr., Sallum EA, Casati MZ. Effect of aluminum oxide-blasted implant surface on the bone healing around implants in rats submitted to continuous administration of selective cyclooxygenase-2 inhibitors. Int J Oral Maxillofac Implants. 2009;24(2):226-233.

32. Cai WX, Ma L, Zheng LW, Kruse-Gujer A, Stubinger S, Lang NP, Zwahlen RA. Influence of non-steroidal anti-inflammatory drugs (NSAIDs) on osseointegration of dental implants in rabbit calvaria. Clin Oral Implants Res. 2015;26(4):478-483.

33. Ribeiro FV, Cesar-Neto JB, Nociti FH, Jr., Sallum EA, Sallum AW, De Toledo S, Casati MZ. Selective cyclooxygenase-2 inhibitor may impair bone healing around titanium implants in rats. J Periodontol. 2006;77(10):1731-1735.

34. Sakka S, Hanouneh SI. Investigation of the effect of ibuprofen on the healing of osseointegrated oral implants. J Investig Clin Dent. 2013;4(2):113-119.

35. Alissa R, Sakka S, Oliver R, Horner K, Esposito M, Worthington HV, Coulthard P. Influence of ibuprofen on bone healing around dental implants: a randomised double-blind placebo-controlled clinical study. Eur J Implantol. 2009;2(3):185-199.

36. Pountos I, Georgouli T, Calori GM, Giannoudis PV. Do Nonsteroidal AntiInflammatory Drugs Affect Bone Healing? A Critical Analysis. ScientificWorldJournal. 2012;2012:606404.

37. Davies JE. Understanding peri-implant endosseous healing. J Dent Educ. $2003 ; 67(8): 932-949$.

38. Fracon RN, Teofilo JM, Satin RB, Lamano T. Prostaglandins and bone: potential risks and benefits related to the use of nonsteroidal anti-inflammatory drugs in clinical dentistry. $\mathrm{J}$ Oral Sci. 2008;50(3):247-352.

39. Wheeler P, Batt ME. Do non-steroidal anti-inflammatory drugs adversely affect stress fracture healing? A short review. Br J Sports Med. 2005;39(2):65-69. 
40. Wang X, Wang Y, Gou W, Lu Q, Peng J, Lu S. Role of mesenchymal stem cells in bone regeneration and fracture repair: a review. Int Orthop. 2013;37(12):2491-2498.

41. Blackwell KA, Raisz LG, Pilbeam CC. Prostaglandins in Bone: Bad Cop, Good Cop? Trends in endocrinology and metabolism: Trends Endocrinol Metab. 2010;21(5):294-301.

42. The National Institute for Health and Care Excellence (NICE). Antiplatelet treatment [Online]. United Kingdom: 2018. Available from: https://cks.nice.org.uk/antiplatelettreatment\#! scenario.

43. Preethanath RS, AlNahas NW, Bin Huraib SM, Al-Balbeesi HO, Almalik NK, Dalati MHN, Divakar DD. Microbiome of dental implants and its clinical aspect. Microb Pathog. 2017;106:20-24.

44. Baqain ZH, Moqbel WY, Sawair FA. Early dental implant failure: risk factors. Br J Oral Maxillofac Surg. 2012;50(3):239-243.

45. Moy PK, Medina D, Shetty V, Aghaloo TL. Dental implant failure rates and associated risk factors. Int J Oral Maxillofac Implants. 2005;20(4):569-577.

46. Alsaadi G, Quirynen M, Komarek A, van Steenberghe D. Impact of local and systemic factors on the incidence of oral implant failures, up to abutment connection. J Clin Periodontol. 2007;34(7):610-617. 


\section{Tables and Table Legends}

Table 1 - Local and systemic patient risk factors for implant failure. ${ }^{30,43-46}$

Table 2 - Summary of common NSAIDS, their acquisition and COX selectivity.

Table 3 - PICOS format which formed part of the search strategy.

Table 4 - Key words used for each database and search results.

Table 5 - Summary of the studies included in this review.

Table 6 - Cochrane risk of bias (RoB 2.0) assessment. 


\begin{tabular}{|l|l|}
\hline Local Factors & Systemic Factors \\
\hline Periodontitis & Age \\
\hline Premature/excessive loading & Smoking status \\
\hline Unfavourable microbiome & Diabetes \\
\hline Poor bone quality & Head and neck radiotherapy \\
\hline & Hormone replacement therapy \\
\hline & Medications such as bisphosphonates and \\
& anti-angiogenics \\
\hline
\end{tabular}

Table 1 - Local and systemic patient risk factors for implant failure. ${ }^{30,43-46}$

\begin{tabular}{|l|l|l|}
\hline NSAID & Acquisition & COX selectivity \\
\hline Ibuprofen & Over the counter & COX-1 and COX-2 \\
\hline Naproxen & Over the counter & COX-1 and COX-2 \\
\hline Aspirin & Over the counter & COX-1 and COX-2 \\
\hline Mefenamic acid & Over the counter & COX-1 and COX-2 \\
\hline Diclofenac sodium & Prescription only & COX-1 and COX-2 \\
\hline Celecoxib & Prescription only & COX-2 \\
\hline Etoricoxib & Prescription only & COX-2 \\
\hline
\end{tabular}

Table 2 - Summary of common NSAIDs, their acquisition and COX selectivity. 


\begin{tabular}{|c|c|c|c|c|}
\hline $\begin{array}{l}\text { Population } \\
\text { of interest }\end{array}$ & Intervention & $\begin{array}{l}\text { Comparison } \\
\text { Intervention }\end{array}$ & Outcome & Study \\
\hline $\begin{array}{l}\text { Any age, } \\
\text { gender or } \\
\text { species } \\
\text { with dental } \\
\text { implant } \\
\text { surgery. }\end{array}$ & $\begin{array}{l}\text { Use of } \\
\text { NSAIDs for } \\
\text { any specified } \\
\text { duration pre, } \\
\text { peri or post- } \\
\text { operatively. }\end{array}$ & $\begin{array}{l}\text { No NSAIDs } \\
\text { used. }\end{array}$ & $\begin{array}{l}\text { Primary criteria: Dental } \\
\text { implant osseointegration } \\
\text { and success. } \\
\text { Success as defined by one } \\
\text { of Smith and Zarb's (1989) } \\
\text { 21 adapted key criteria: } \\
\text { 1. The implant is } \\
\text { immobile when } \\
\text { clinically tested. } \\
\text { No radiographic } \\
\text { discomfort or } \\
\text { evidence of any } \\
\text { peri-implant } \\
\text { analysis with no } \\
\text { radiolucency. } \\
\text { of } \\
\text { Mean vertical bone } \\
\text { loss is less than }\end{array}$ & $\begin{array}{l}\text { Randomised } \\
\text { control } \\
\text { trials. }\end{array}$ \\
\hline
\end{tabular}




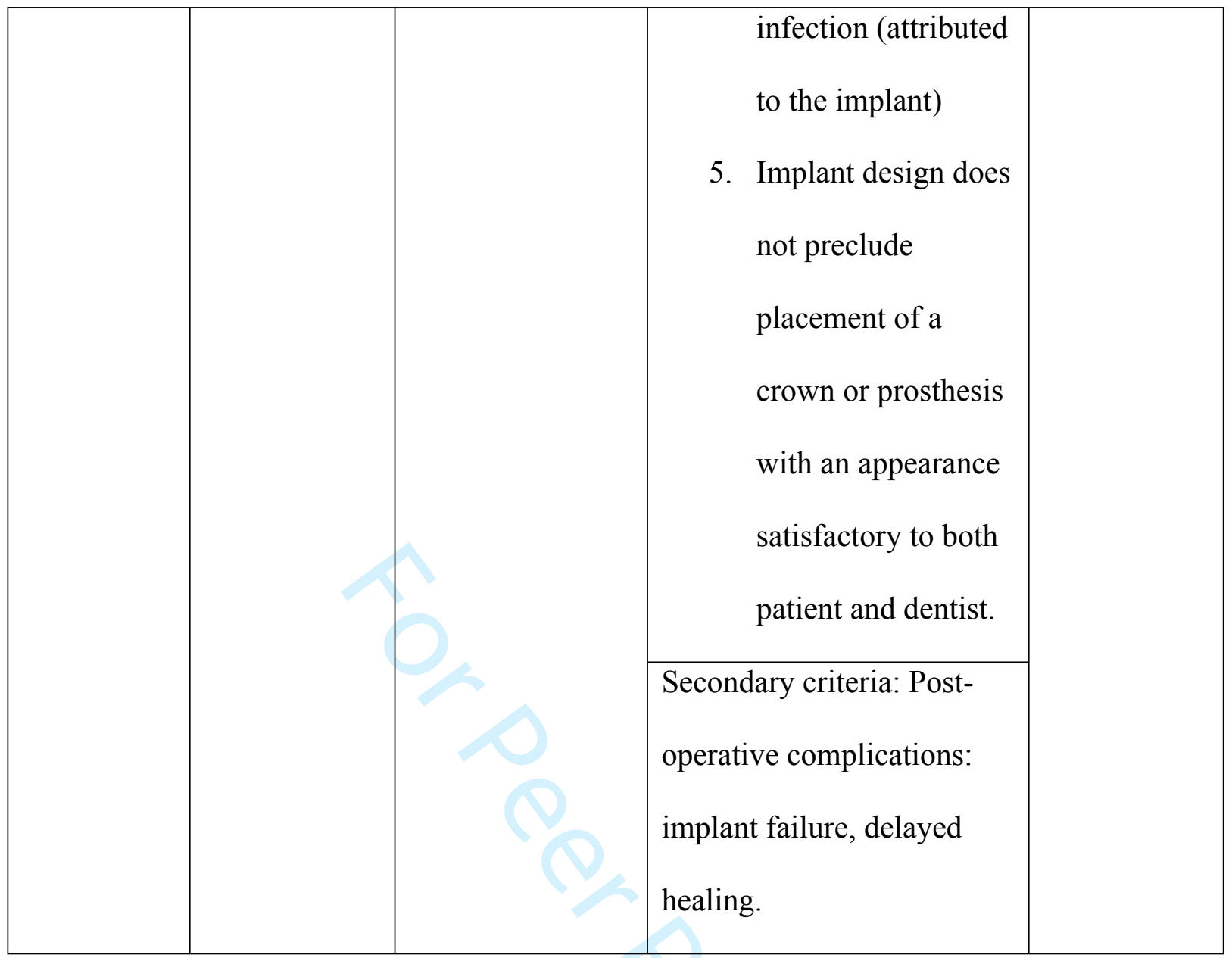

Table 3 - PICO format which formed part of the search strategy. 


\begin{tabular}{|l|l|l|}
\hline Number & Searches & Results \\
\hline 1 & Dental implants & 34353 \\
\hline 2 & Implant surgery & 5734 \\
\hline 3 & 1 or 2 & 38979 \\
\hline 4 & Non steroidal anti inflammatory drugs & 24088 \\
\hline 5 & NSAIDS & 47655 \\
\hline 6 & Cyclooxygenase & 131497 \\
\hline 7 & COX & 338392 \\
\hline 8 & 4 or 5 or 6 or 7 & 452818 \\
\hline 9 & Osseointegration & 18487 \\
\hline 10 & Healing & 425823 \\
\hline 11 & Success & 543474 \\
\hline 12 & 9 or 10 or 11 & 970727 \\
\hline 13 & 3 and 8 and 12 & \\
\hline
\end{tabular}

Table 4 - Key words used for each database and search results. 


\begin{tabular}{|c|c|c|c|c|c|c|c|c|}
\hline Study & $\begin{array}{l}\text { Study } \\
\text { Design }\end{array}$ & $\begin{array}{l}\text { Patient } \\
\text { Details } \\
\text { (Species, } \\
\text { age, sex) }\end{array}$ & $\begin{array}{l}\text { Number of } \\
\text { participants }\end{array}$ & $\begin{array}{l}\text { Participant } \\
\text { Distribution }\end{array}$ & $\begin{array}{l}\text { Intervention } \\
\text { Details }\end{array}$ & Follow up & $\begin{array}{l}\text { Outcomes } \\
\text { Assessed }\end{array}$ & Key Results \\
\hline $\begin{array}{l}\text { Cai et } \\
\text { al. } \\
(2015)^{32}\end{array}$ & $\begin{array}{l}\text { Randomised } \\
\text { control trial. }\end{array}$ & $\begin{array}{l}\text { Rabbits, } \\
6-9 \\
\text { months } \\
\text { old, } \\
\text { sex not } \\
\text { specified. }\end{array}$ & 18 & $\begin{array}{l}\text { Randomised into } \\
\text { three groups: } \\
\text { 1. Control group } \\
\text { with no post- } \\
\text { operative pain } \\
\text { relief. } \\
2 \text {. Group with } \\
\text { Diclofenac } \\
\text { Sodium } \\
2 \mathrm{mg} / \mathrm{kg} / \text { day } \\
\text { orally. } \\
\text { 3. Group with }\end{array}$ & $\begin{array}{l}\text { All rabbits } \\
\text { underwent } \\
\text { insertion of a } \\
\text { dental } \\
\text { implant into } \\
\text { the calavarial } \\
\text { bone. } \\
\text { Post- } \\
\text { operative } \\
\text { pain relief } \\
\text { was } \\
\text { continued for }\end{array}$ & $\begin{array}{l}\text { At weeks } 4 \\
\text { and } 12 \text { post } \\
\text { surgery, } \\
\text { three } \\
\text { rabbits } \\
\text { from each } \\
\text { of the } \\
\text { groups } \\
\text { were } \\
\text { sacrificed. }\end{array}$ & $\begin{array}{l}\text { Micro-CT analysis } \\
\text { to investigate bone } \\
\text { volume ratio, } \\
\text { trabecular } \\
\text { thickness, mean } \\
\text { trabecular number } \\
\text { and separation. } \\
\text { Histomorphometric } \\
\text { analysis to } \\
\text { quantitatively } \\
\text { assess the }\end{array}$ & $\begin{array}{l}\text { Micro-CT analysis: } \\
\text { no significant } \\
\text { differences found. } \\
\text { Histomorphometric } \\
\text { analysis: no } \\
\text { significant } \\
\text { differences found. }\end{array}$ \\
\hline
\end{tabular}

Page $\mathbf{2 6}$ of $\mathbf{3 0}$ 


\begin{tabular}{|c|c|c|c|c|c|c|c|c|}
\hline & & & & $\begin{array}{l}\text { Parecoxib } \\
1.5 \mathrm{mg} / \mathrm{kg} / \text { day } \\
\text { subcutaneously } \\
\text { injected. }\end{array}$ & one week. & & $\begin{array}{l}\text { percentage of bone } \\
\text { to implant contact. }\end{array}$ & \\
\hline $\begin{array}{l}\text { Ribeiro } \\
\text { et al. } \\
(2006)^{33}\end{array}$ & $\begin{array}{l}\text { Randomised } \\
\text { control trial. }\end{array}$ & $\begin{array}{l}\text { Rats, } \\
10 \text { weeks } \\
\text { of age, } \\
\text { sex not } \\
\text { specified. }\end{array}$ & 31 & $\begin{array}{l}\text { Randomised into } \\
\text { two groups: } \\
1 . \\
\text { Administration } \\
\text { of subcutaneous } \\
1 \mathrm{ml} / \mathrm{kg} \text { of saline } \\
\text { solution for } 60 \\
\text { days. } \\
2 . \\
\text { Administration } \\
\text { of subcutaneous } \\
3 \mathrm{mg} / \mathrm{kg} \text { of }\end{array}$ & $\begin{array}{l}\text { Dental } \\
\text { implants } \\
\text { were inserted } \\
\text { into the } \\
\text { tibiae of all } \\
\text { rats. } \\
\text { Continuation } \\
\text { of anti- } \\
\text { inflammatory } \\
\text { or saline } \\
\text { medicaments }\end{array}$ & $\begin{array}{l}\text { All rats } \\
\text { were } \\
\text { sacrificed } \\
\text { at } 60 \text { days. }\end{array}$ & $\begin{array}{l}\text { Histological } \\
\text { analysis to } \\
\text { determine bone to } \\
\text { implant contact, } \\
\text { bone area and bone } \\
\text { density for both } \\
\text { cortical and } \\
\text { cancellous bony } \\
\text { regions. }\end{array}$ & $\begin{array}{l}\text { Meloxicam } \\
\text { significantly } \\
\text { reduced bone } \\
\text { healing arounds } \\
\text { implants. This } \\
\text { included bone to } \\
\text { implant contact, } \\
\text { bony area and bone } \\
\text { density for cortical } \\
\text { and cancellous } \\
\text { bone. }\end{array}$ \\
\hline
\end{tabular}

Page $\mathbf{2 7}$ of $\mathbf{3 0}$ 


\begin{tabular}{|c|c|c|c|c|c|c|c|c|}
\hline & & & & $\begin{array}{l}\text { Meloxicam for } \\
60 \text { days. }\end{array}$ & $\begin{array}{l}\text { until } \\
\text { sacrifice. }\end{array}$ & & & \\
\hline $\begin{array}{l}\text { Alissa et } \\
\text { al. } \\
(2009)^{35}\end{array}$ & $\begin{array}{l}\text { Randomised } \\
\text { control trial. }\end{array}$ & $\begin{array}{l}\text { Humans, } \\
\text { age range } \\
17-87 \\
\text { years. } \\
37 \\
\text { females } \\
\text { and } 24 \\
\text { males. }\end{array}$ & 61 & $\begin{array}{l}\text { Patient randomly } \\
\text { allocated to the } \\
\text { Ibuprofen or } \\
\text { placebo group } \\
\text { (oral } \\
\text { administration). }\end{array}$ & $\begin{array}{l}\text { Dental } \\
\text { implants } \\
\text { placed in all } \\
\text { patients. } \\
\text { Ibuprofen or } \\
\text { placebo were } \\
\text { continued for } \\
\text { one week } \\
\text { post } \\
\text { operatively. }\end{array}$ & $\begin{array}{l}\text { Follow up } \\
\text { at } 2 \text { weeks } \\
\text { (baseline), } \\
3 \text { months } \\
\text { and } 6 \\
\text { months. }\end{array}$ & $\begin{array}{l}\text { Radiographic } \\
\text { examination to } \\
\text { determine marginal } \\
\text { bone levels at the } 3 \\
\text { month and } 6 \text { month } \\
\text { recall } \\
\text { examinations. }\end{array}$ & $\begin{array}{l}\text { There were no } \\
\text { statistically } \\
\text { significant } \\
\text { differences } \\
\text { between groups for } \\
\text { marginal bone } \\
\text { level changes at } 3 \\
\text { months or } 6 \\
\text { months compared } \\
\text { to baseline. }\end{array}$ \\
\hline
\end{tabular}

Table 5 - Summary of the studies included in this review. 


\begin{tabular}{|c|c|c|c|}
\hline & Cai et al. (2015) ${ }^{29}$ & $\begin{array}{l}\text { Ribeiro et al. (2006) } \\
30\end{array}$ & Alissa et al. (2009) ${ }^{32}$ \\
\hline $\begin{array}{l}\text { The randomisation } \\
\text { process }\end{array}$ & $?$ & ? & \\
\hline $\begin{array}{l}\text { Deviations from } \\
\text { intended } \\
\text { interventions }\end{array}$ & & & \\
\hline $\begin{array}{l}\text { Missing outcome } \\
\text { data }\end{array}$ & & & \\
\hline $\begin{array}{l}\text { Measurement of the } \\
\text { outcome }\end{array}$ & & & \\
\hline $\begin{array}{l}\text { Selection of the } \\
\text { reported result }\end{array}$ & & 2 & \\
\hline Overall risk of bias & & & \\
\hline
\end{tabular}

Table 6 - Cochrane risk of bias (RoB 2.0) assessment. 


\section{Figure Legends}

Figure 1 - Summary of the cellular mechanism of bone remodelling during fracture injury. Adapted with permission from Journal of Cell Science (DOI: 10.1242/jcs.063032). ${ }^{5}$

Figure 2 - PRISMA flow diagram showing the flow of studies through the review process.

Figure 3 - Overall risk of bias (assessed with the Cochrane RoB 2.0 tool) for randomised control trials included in this review. 


\section{The bone remodelling cycle}

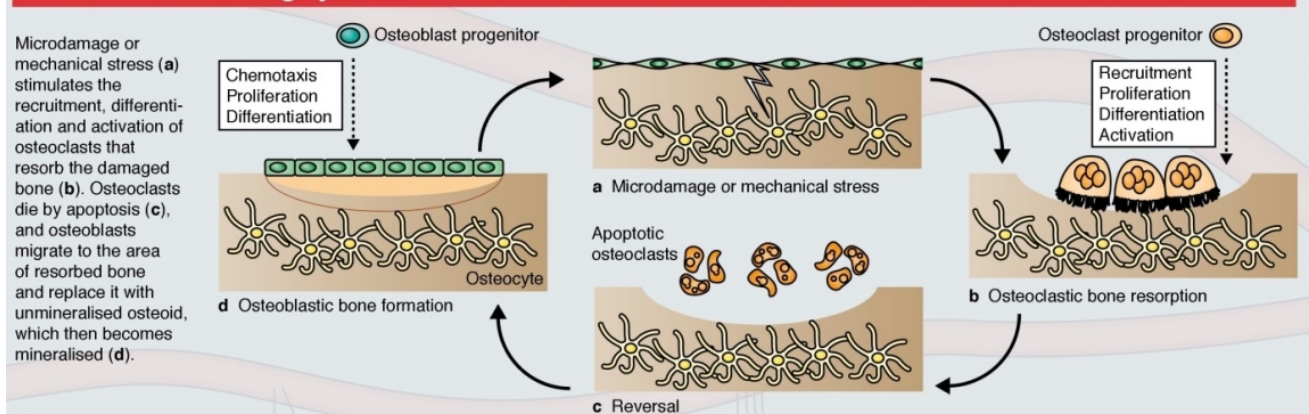

Summary of the cellular mechanism of bone remodelling during fracture injury. Adapted with permission from Journal of Cell Science (DOI: 10.1242/jcs.063032). 5

$159 \times 55 \mathrm{~mm}(220 \times 220 \mathrm{DPI})$ 


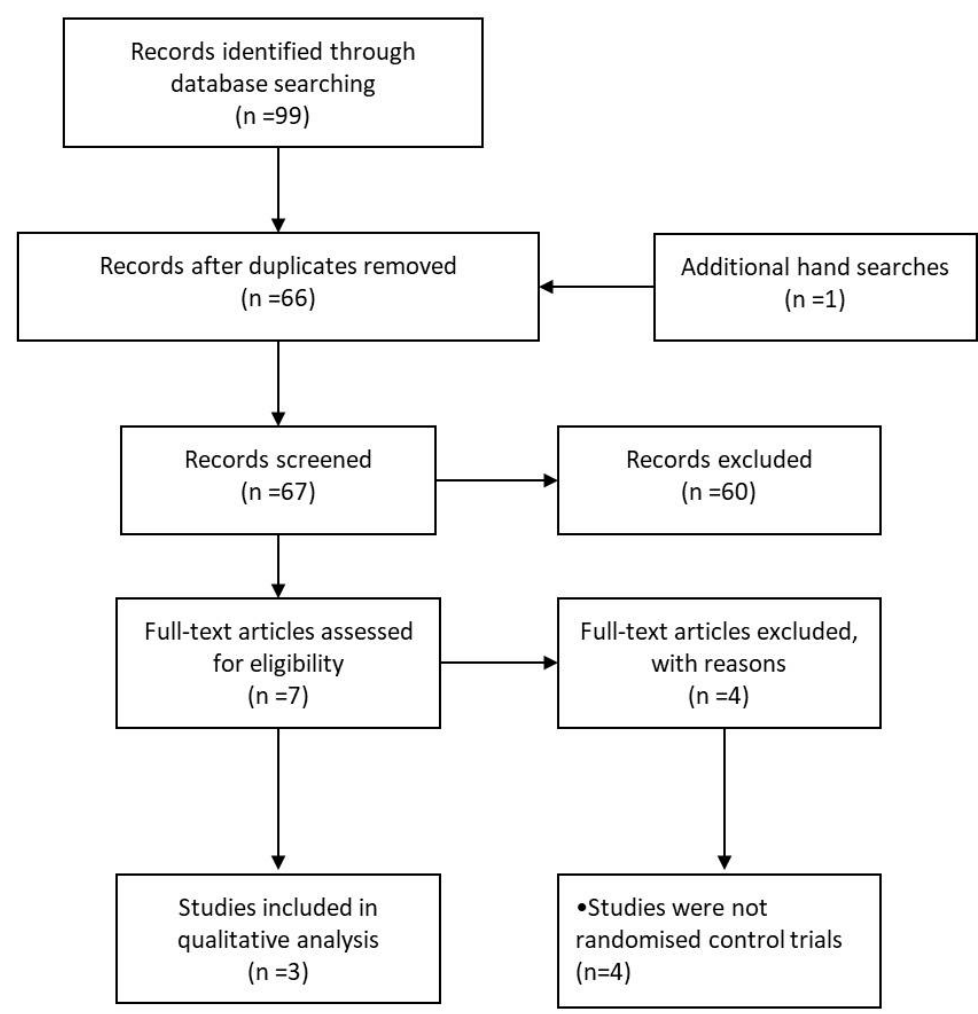

PRISMA flow diagram showing the flow of studies through the review process.

$192 \times 171 \mathrm{~mm}(150 \times 150 \mathrm{DPI})$ 
Overall risk of bias (assessed with the Cochrane RoB 2.0 tool) for randomised control trials included in this review.

$387 \times 219 \mathrm{~mm}(96 \times 96 \mathrm{DPI})$ 